UDC 316.77(4+477)

DOI: https://doi.org/10.30839/2072-7941.2018.149675

\title{
INFORMATIONAL AND COMPUTER COMMUNICATIONS OF SCIENTIFIC AND EDUCATIONAL ACTIVITIES IN UKRAINE INTEGRATION CONDITIONS IN EUROPEAN EDUCATIONAL SPACE
}

\author{
(C) SOSNIN, O. V. \\ Academician Member of the Ukrainian Academy of Political Science (Kyiv, Ukraine) \\ E-mail: alvas.sosnin@gmail.com, ORCID: 0000-0003-4188-0887
}

(C) AZHAZHA, M. A.

Zaporozhye State Engineering Academy (Zaporizhzhya, Ukraine)

E-mail: azazmarina17@gmail.com, ORCID: 0000 -0001-6067-3926

\begin{abstract}
The relevance of the research is that the information and computer communications of scientific and educational activity as a factor of the development of the information society are analyzed. Statement of the task - the modern stage of the sociopolitical development of Ukraine is characterized by the unprecedented pace of development of a new information and communication arrangement of scientific and educational activities in society and, as a result, its development as informational and civic. Object of research information and computer communications of scientific and educational activity as a complex social, cultural and economic phenomenon. The subject of research is the influence of the information society on the development of information and computer communication of scientific and educational activities. Analysis of recent publications and research. The author focuses on the analysis of the problems of the informational society, which was investigated in the works of I. Wallerstain, Z.Bzhezynsky, D. Bell, J.Gelbreyt, P.Drucker, A.Lazarevich, A.Porter, O.Toffler, and R.Hatcheson, as well as in the works of domestic scientists - V. Andrushchenko, V.Voronkova, O.Kivlyuk, M.Kyrychenko, A.Punchenko, D.Sviridenko. Selection of unexplored parts of the general problem. Unsolved earlier part of the general problem. Setting objectives. Representatives of the modern scientific and educational environment did not notice in due time that with the advent of the computer in the world fundamental concepts of education, man, science, the Universe, temporal measurements of time, tendencies of the development of the modern world have changed significantly. Education determines the pace of world development, and the ownership of its markets began an unprecedented rigorous competition. Information and knowledge have become a tremendous wealth, an intangible asset to the development of nations and states. Methodology of the research - the use of synergistic and axiological methods that contribute to deep penetration into the essence of the object and subject of research. Scientific novelty of the research. This scientific study involves addressing the socio-philosophical meaning of the concept of information and computer communications of scientific and educational activity as a factor in the development of the information society. Presenting the main material: the problems concerning the global informatization of the society that stimulated all processes of international cooperation of people have been revealed; due to the development of the information and communication sphere, the needs of management systems of the states, societies and their citizens in various informational services have been determined, radical changes in all security systems of socio-political relations; the historical tendency of development of industrial, then - postindustrial and informational society on the basis of the concept of J.Masuda is analyzed; it was disclosed that the progress of the information and

Informational and computer communications of scientific and educational activities in Ukraine integration conditions in European educational space
\end{abstract}


education problem requires us to improve considerably the educational information and communication systems and technologies of education; the directions of improvement of information and computer communications of scientific and educational activity as the factor of development of the information society are substantiated. Conclusions - the concept of information and computer communications of scientific and educational activity as a factor of development of the information society is formed. The result of the research is the development of the directions of reforming (modernizing) the education system in Ukraine and the use of concepts for the introduction of computer information and communication technologies for these purposes.

Key words: information and computer communications, scientific and educational activity, industrial society, information society, modernization of education

The problem in general terms and its connection with important scientific or practical tasks. Relevance of research topic.

The modern stage of the sociopolitical development of Ukraine is characterized by unprecedented rates of development of a new information and communication arrangement of scientific and educational activity in society and, as a result, its development as informational and civic. It is logical that this is a legally defined goal of the development of our state, since people are opposed to any challenges and dangers solely at the expense of education. All the leading countries of the world have achieved their position precisely because they have all been trying to provide the opportunity to obtain high-quality education for the bulk of their citizens.

Analysis of recent research and publications. We rely on the authors who studied the problems of the informational society - $\mathrm{I}$. Walererstein, Z.Bzhezynsky, D. Bell, J.Gelbright, P.Drucker, A.Lazarevich, A.Porter, A.Toffler, and R.Hatcheson, as well as native ones - V. Andrushchenko, V.Voronkova, O.Kivlyuk, A.Punchchenko.

\section{Selection of unexplored parts of} the general problem. Unsolved earlier part of the general problem. Setting objectives. Representatives of the modern scientific and educational environment, unfortunately, did not notice in due time that with the advent of the computer in the world fundamental concepts of education, man, the Universe, temporal dimensions of time, tendencies of the modern world changed significantly. Education determines the pace of world development, and the ownership of its markets began an unprecedented rigorous competition. Information and knowledge have become a tremendous wealth, an intangible asset to the development of nations and states.

The purpose of scientific research is the conceptualization of information and computer communications of scientific and educational activity as a factor in the development of the information society.

\section{This goal is realized in a number of tasks:}

- to identify problems concerning the global informatization of society, which stimulated all processes of international cooperation of people, due to the development of the 
information and communication sphere, increased the needs of management systems of states, societies, their citizens in various information services, led to radical changes in all security systems of socio-political relations;

- to analyze the historical trend of the development of the industrial, then - post-industrial and informational society on the basis of the concept of J.Masuda;

- to reveal the provision that the progress of the information and education problem requires us to weighed up the educational information and communication systems and technologies of education.

- to substantiate directions of improvement of information and computer communications of scientific and educational activity as a factor of development of the information society.

Object of research - information and computer communications of scientific and educational activity as a complex social, cultural and economic phenomenon.

The subject of the research is the influence of the information society on the development of information and computer communication of scientific and educational activities.

Methodology of the research the use of synergistic and axiological methods, which contribute to the deep penetration of the essence of the object and subject of the research.

\section{Presenting of the main material}

With the advent of computers and computerized communications, new information and technological realities of communication appeared, which create in all spheres of human activity previously unheard of the form and content of life situations.

The conditions and meaning of scientific and educational activities, especially as regards the definition of legal rights and freedoms of the person for the information accumulated by the global society that we inherit, radically changed. They are not always covered by the definitions of classical knowledge and political and legal decisions, and therefore provide conceptualization to our actions to overcome the problems that arise, in particular, with regard to information security as a condition of sustainable and innovative development of the state, is a trend of development of modern society, that is, especially actual a problem.

The conceptual foundations of human rights and freedoms, substantiated over centuries, in the context of the problems of global informatization have significantly lost their relevance, a new set of problems, in particular the security of information and communication itself, has emerged that we did not have the slightest idea of before. Their occurrence is due to the unprecedented penetration of ICT in all spheres of human life in the face of the globalization of the information and communication environment, the integration of problems in communication networks.

The analysis of recent researches and publications shows that global informatization of society stimulated all processes of international cooperation of people, thanks to the 
development of the information and communication sphere, increased the needs of management systems of states, societies, their citizens in various informational services, led to radical changes in all security systems of socio- political relations. Against the background of previously unprecedented pace of introduction of computer technology and ICT into the education there are not only profound changes in the scientific and educational activities of the countries of the world, but also the division of the world into the center and periphery (according to the landscape of the world economy).

J. Masuda gives us a complete picture of the information society, based on a historical analogy with the pattern of industrial society. In concentrated form, it presents the historical trend of the development of the industrial, then - the postindustrial and information society.

The first innovative technology in the industrial society is the steam engine. Its main function was to replace and improve human physical labor. In the information society, the initial innovative technology is computer technology, and its main function is the replacement and improvement of human mental work.

In an industrial society, the energy revolution (as a derivative of the invention of the steam engine) has dramatically increased the material and productive power of man and made it possible the mass production of goods and services, as well as the accelerated transportation of goods. In a new society, the information revolution (as a derivative of computerization) dramatically increases the intellectual and productive capacities of a person and enables mass production of cognitive information and systematic knowledge. In industrial society, markets have expanded as a result of the opening of new continents and the conquest of the colonies. Increasing the purchasing power of people in the process of consumer race was the main factor in the expansion of the market. In the information society, the frontier of knowledge will determine the potential market and the dynamic expansion of opportunities for solving problems will be the main factor in the expansion of the information market.

In the industrial society, the leading branches of the economy are machine building and chemistry. The information society will lead the intellectual industry, the core or the heart of which will be the knowledge industry.

The economic structure of an industrial society has an economy:

1) consumer goods;

2) special consumption;

3) separation of production and consumption between enterprises and households. In the information society: A) a synergistic economy will change the economy of exchange; $B$ ) Information, as the axis of socioeconomic development, will be conducted by information services; C) the self-generation of information by users will be expanded;

4) This accumulated information will be expanded through synergistic production and sharing.

In industrial society, the law of force, as a universal socioeconomic principle, manages the balance of 
supply and demand, maintaining economic order. In the information society, the principle of general purpose, as the fundamental principle of society, will govern the order in society.

In an industrial society, the most important subject of social activity is an enterprise, or an economic group. In the information society, the subject of social activity is a voluntary community or socio-economic group. In an industrial society, the socioeconomic system appears as a system of private enterprises characterized by private ownership of capital, free competition and maximization of profits. In the information society, the socioeconomic system will be a voluntary civil society characterized by the supremacy of infrastructure, which is formed both by social capital and intellectual capital, as well as the principle of synergy and public benefit.

Industrial society is a society with centralized authority and class hierarchy. On the contrary, the information society will be multicentre, horizontally functional, voluntary, where social order will be supported by autonomous and complementary functions of voluntary civil society. The purpose of an industrial society is to ensure the material well-being of citizens throughout their lives. The information society will strive to realize the value of time, which (realization) projects and updates the future time for each human being. The goal of society will be the enjoyment of every worthy life in search of great future opportunities.

The political system of industrial society is a parliamentary system and a majority government. In the information society, the political system will be based on participatory democracy. It will be a policy of autonomous self-government of citizens based on consent, participation and synergy, and also takes into account minority views. In industrial society, labor collectives are engines of social change. In the information society, social movements will be the leading force in social change; their weapons will be the organization of public hearings and courts.

In industrial society, there are three main types of social problems: increasing unemployment, international conflicts that go into war, and fascist dictatorship. Problems of the information society will be: a) futuroshock, generated by the inability of people to adequately respond to sharp social transformations; b) terrorist acts committed by single people or organized groups of people; c) invasion of the private life of people; d) the crisis of a controlled society.

The highest stage of industrial society is a mass consumer society (high levels of mass consumption, increasing population dynamics). The higher stage of the information society is a high level of its creativity, a society based on the mass production of knowledge, in which computerization creates conditions for cognitive creativity and selfimprovement of each individual. In 
industrial society, material values that meet the physiological and physical needs of people are universal standards for all social values. In the information society, the universal standard of values will become a sense of satisfaction from the goal.

The spirit of industrial society was a Renaissance spirit of human liberation, which means respect for fundamental human rights and respect for the dignity of the individual. The spirit of the information society will be the spirit of globalism. This is a symbiosis in which man and nature can live in harmony, where the spirit of strict self-discipline and social indemnity will reign.

Formation of the information society J. Masuda connects with his computerization. He highlights four stages of computerization: 1) science; 2) management; 3 ) society (system of education, medicine, social security, etc.); 4) at the level of individuality. Today, a huge number of facts suggests a decline in the level of organization of processes of general and vocational education in Ukraine, its de-ideologization, etc. The domination of separate countries and Ukraine's dependence on them is a very prominent phenomenon in the new system of information relations, characterized by a variety of nonlinear processes, sometimes complex manifestations.

Representatives of the modern scientific and educational environment, unfortunately, did not notice in due time that with the advent of the computer in the world fundamental concepts of education, man, the Universe, temporal dimensions of time, tendencies of the modern world changed significantly. Education determines the pace of world development, and the ownership of its markets began an unprecedented rigorous competition. Information and knowledge have become a tremendous wealth, an intangible asset to the development of nations and states.

Today, only on the understanding of this, we have the hope that, working with a well-protected from the corruption of information, that is, in a global and secure information and communication environment, we are able to compete in the scientific, educational, scientific and technical spheres. By avoiding deindustrialization of the country, introducing our borrowed and innovative ideas into scientific and educational activities, we are able to withstand the $21 \mathrm{st}$ century and constantly update the trends of innovation development in science, education, industry, agriculture, etc.

The power circles of Ukraine, after all, realized that under the influence of the rapid growth of the pace of world scientific and technological and technological progress, information and education problems acquired the features of the national, became more multidimensional - social, spiritual and, in general, the natural and economic trends of the successful development of the information and communication type society, demanding from us a balanced arrangement of educational information and communication systems and technologies of education.

The main task for success is to provide the person who studies, 
teaches or develops scientific and technical ideas, scientific, technical and commercial potential of Ukraine, economic, legal, organizational and political support. Society, in the end, has learned to appreciate such qualities as human ability to study and invention.

The government should ensure the implementation of innovative opportunities in the scientific and educational sphere, legislation, protect intellectual property and encourage inventors. Under such conditions, the political system must finally tackle corruption urgently, develop technological innovation, and promote successful scientists and entrepreneurs with "social lifts" at the highest levels of state governance.

In order to overcome the many negative defects and trends accumulated by our society, in our opinion, the society, first of all, it is necessary to change the attitude of science and education on the principles of a technical, informational and information culture, at the legislative level. This kind of culture, which has already rooted in world university practice, means belief in the natural force of development of scientific and technological progress as a key component in the overall dimension of human progress.

One can even try to formulate some principles of creating a system of personnel training, which is at the core of it, namely: competition between work personnel and management personnel; business reputation and initiative; achievement; multi-profile; quality; product consumers; information support; sales forms; financial and resource services that are not objectionable. This is what we think it is necessary to hold a conversation about the reform of higher education in order to prepare national elite capable of innovative scientific and technical work capable of working on global markets for goods and services.

The success of the implementation of the achievements of scientific and technological progress made Ukraine more prominent in the twentieth century, but the informatization of the world of information and communication environment put before us new complex tasks of organizing the transfer of our own technologies to the world markets of goods and services - all that is associated with the transfer knowledge. Describing the changes that have taken place in this sphere, we cannot but speak of unprecedented growth rates of the influence of information and communication factors on the development of domestic science, socio-economic existence in general, whatever the conceptual names we have not given it - post-industrial, informational, market, civil, etc.

Today, all information and communication processes of the transfer of content information and knowledge become a real instrument of interaction for all components of society and a means of achieving compromises in the event of the adoption of agreed solutions at any level. Unfortunately, modern methods and the culture of working with information have created in the minds 
of people and virtual reality, which contributes to the growth of massive illusions, distracting from the real world.

We sometimes face a huge problem area of information and communication elements, which requires not only deep scientific research in the field of organization of scientific and technical activities, which we have almost not conducted, because they require new approaches to systematization of regulatory actions in the information and communication activities.

Information competence, which is generally understood as the ability to find information with the help of modern technical means, as well as to store, process and apply it, is rightfully considered as the necessary property of a person for information during the age of globalization. And precisely in the context of the implementation of NBICS technologies, today in the world under the most critical circumstances a new lifestyle is being formed, traditional intrinsic orientations are significantly transformed, there are themes for new discussions on measuring the values of society and man.

Another important characteristic and competitive factor of modern society is the dynamics of the changes that take place and the aspirations of people for novelty and novelty. It is obvious that under the influence of computerization and the latest information and communication technologies (ICT) a new social reality arises and is based on already unusual (obsolete) methods that by themselves destroy the meaning of modern ideas about governance, resources and methodology.

At all times, the development of basic and applied sciences, scientific and educational activities was the development of industrial, agricultural, medical and other technologies, the arrangement of socio-political and socio-economic relations, which characterized progress.

However, the change of epochs, which is accompanied by today's technologically-globalized renewal of society, changes in the perceptions about the effectiveness of technologies in modern management, their convergence at all levels is more important in determining the capabilities of states in the creation and application of new scientific and educational technologies based on the achievements of science. Knowledge is now the basis of any transformation and, as a consequence, change the mentality of peoples from different countries of the world (the scale and pace of social modernization in them vary considerably).

System-building principles for the formation of new organizational and managerial paradigms of scientific and educational activity of the system become innovations, novelty. Innovation is not only the most popular system for assessing the state and prospects of community development, but also the basic principle, the factor of the structuring of the contemporary worldview and life, and determines the place of a person in the world.

Today, innovation activity in virtually all areas has created a situation that is almost impossible to 
control outdated, based on classical science, management technologies. The variability of the situation is so varied and large that it cannot even be realized (it infinitely critically complicates its perception) through separate discoveries of scientific research or social events. As a result, there is a need for new types of rationality created by scientific and educational systems.

Scientific knowledge overcomes the existing boundaries of sciences and aspires to transdisciplinary integration. With the advent of computers and new ICT in the second half of the 20th century, the dynamics of human development, societies and countries increased, requiring the institutionalization of the production of scientific knowledge in new universities, polytechnic and technological institutes.

Today, in order to win or even survive in a globally competitive economic system, it is necessary to invest more rationally in the development of education, where, quite clearly, the very concept of the necessity of innovations, not only innovative products, but also a special "specialized labor force" capable of producing new knowledge as an intellectual capital and resource for the development of man, country and society. The quality of our work here will be the answer to the global socioeconomic challenges that require a new convergent science, the creation of converged nanoscience, bioinformatics, cognitive technologies, with which there are hopes of solving global problems with a significant improvement in the quality of life.

\section{Conclusions}

The changes that have taken place due to computerization over the past 30 years have been so profound and ambitious that they have touched upon the core of social life and the lifestyle of all people and peoples.

Their theoretical illumination has found its place in a number of new concepts of social development, which appeared in the XX century through the notion of "information society". It entered the world scientific and socio-political terminology field, and today there is a large number of definitions of this phenomenon. It is called industrial, the postmodern era, society of knowledge, scientific, telematic, postoil, etc.

Modifications of the concept in different countries demonstrate sociopolitical, social, scientific and educational perspectives for the development of the phenomenon, such as: "national information infrastructure" (USA), "information society" (Council of Europe), "information trunk" (Canada, Great Britain) The importance of the creation and development of the information society on March 27, 2006 was underlined by the UN General Assembly, which adopted a resolution on the proclamation of May 17, 2006 as the International Day for the Information Society.

In the world, with the help of modern ICTs, powerful information flows have been created to serve the needs of the consumer society. They exist exclusively as a layer of the 
Earth's shell, and global information and communication projects produce with it effective means and methods of forming parliamentary, power and scientific and educational elites, regulating and calming the ideas of patriots and citizens, suppressing and leveling at any cost their creativity impulses on the organization of productive activities of the people.

Consequently, the development of concepts for the effective use of information technologies in the context of Ukraine's integration into the European educational space is considered as one of the directions of modernization of education.

Education contributes to the emergence of new educational opportunities, perspective forms, methods and means of training, and their implementation in the process of training highly skilled professionals. Expanding the scope of accumulated problems, Ukraine, of course, has to go on an unprecedented reform of the development of the information and communication sphere of education. Corruption and the bureaucracy invented by the formal imitation of useful activity has become the scale of this disaster.

All of this devalues the most interesting and intelligent ideas of creative thinking citizens of Ukraine, turns their useful initiatives into something completely opposite to the intentions.

\section{REFERENCES}

\section{REFERENCES}

1. Andryukaytene, R., Voronkova, V., Kivlyuk, O., Romanenko, T., Rizhova, I. (2017). Konceptualizaciya smart-obshchestva i smart-tekhnologiy $\mathrm{v}$ kontekste razvitiya sovremennoy civilizacii. Mokslas ir praktika: aktualijos ir perspektyvos, 11-12.

2. Bilohur, V. Ye. (2011). Svitohliadni oriientatsiyi studentiv: tendentsiyi zmin u transformatsiynomu suspilstvi. Dnipropetrovsk: Porohy, 311.

3. Vlasenko, F. P. (2014). Virtualna realnist yak prostir sotsializatsiyi indyvida. Humanitarnyi visnyk Zaporizkoi derzh. inzhenernoi akademiyi, 56, 208-217.

4. Voronkova, V. G.; Bazaluka, O. A. (Ed.) (2012). Formirovanie novogo mirovozzreniya, novogo cheloveka, novogo obshchestva budushchogo. Kogo i kak vospityvat' v podrastayushchih pokolenih. Vol. 2. Kyiv: Izdatel'skiy dom «Skif», 134-152.

5. Voronkova, V. G. (2015). Grazhdanskoe obshchestvo kak paradigma, koncept i konstrukt social'no-filosofskogo diskursa. Philosophy \& Cosmology, 15, 198-215.

6. Gaponenko, A. L., Orlova, T. M. (2008). Upravlenie znaniyami. Kak prevratit' znaniya v kapital. Moscow: Eksmo, 400.

7. Dzoban, O., Sosnin, O. (2015). Informatsiyna bezpeka: novi vymiry zahroz, poviazanykh z aktyvizatsieiu mizhnarodnoi diyalnosti $\mathrm{v}$ informatsiyno-komunikatsiyniy sferi. Visnyk Lvivskoho universytetu, 37, 35-43.

8. Sosnin, O. V., Voronkova, V. H., Nikitenko, V. O., Maksymeniuk, M. Yu. (2017). Informatsiyno-komunikatyvnyi menedzhment: zarubizhnyi ta vitchyznianyi dosvid. Kyiv: Politekhnika, 316.

9. Kyvliukb, O. P. (2017). Formuvannia elementiv kompiuternoi hramotnosti molodshykh shkoliariv. Kyiv, 210.

10. Kyvliuk, O. P. (2014). Modeliuvannia informatsiynykh protsesiv v konteksti informatyzatsiyi suspilstva. Hileia, 80, 222-226.

11. Kremen, V. H. (2009). Filosofiya liudynotsentryzmu v stratehiyakh osvitnoho prostoru. Kyiv: Pedahohichna dumka, 520. 
12. Kremen, V. H. (2012). Synerhetyka v osviti: kontekst liudynotsentryzmu. Kyiv: Pedahohichna dumka, 368.

13. Kremen', V. G.; Mel'nikov, L. G. (Ed.) (2005). K obshchestvu znaniy - cherez sovershenstvovanie sistemy obrazovaniya. Social'no-ekonomicheskie problemy informacionnogo obshchestva. Sumy: ITD «Universitetskaya kniga», 34-48.

14. Masuda, Y. (1983). Information Society as Postindustrial Society. Wash., 234.

15. Kirichenko, M. O. (2016). Conceptualization of cognitive-communicative dimensions of the ideology of the information society in the humanities and scientific discourse: research methodology. Gileya, 116, 137-141.

16. Kirichenko, M. O. (2017). Informatiology as a component of formation of ideology of information society. Gumanitarniy visnik Zaporizkoi ZDIA, 69, 105-111.

17. Kutsepal, S. V. (2006). Osvita v hlobalizatsiyno-informatsiynomu kontynuumi: neobkhidnist transformatsiyi. Filosofski obriyi. Kyiv; Poltava, 15, 27-40.

18. Kusherets, B. I. (2002). Znannia yak stratehichnyi resurs suspilnykh transformatsiy. Kyiv, 248.

19. Punchenko, O. P. (2013). Civilizacionnoe izmerenie istorii chelovechestva. Odessa: Astroprint, 448.

20. Punchenko, O. P. (2015). Informatyzatsiya yak zasib reprezentatsiyi informatsiynykh resursiv suspilstva. Humanitarnyi visnyk Zaporizkoi derzh. inzhenernoi akademiyi, 63, 21-30.

21. Sosnin, O. V. (2015). Informatsiyna bezpeka: novi vymiry zahroz, poviazanykh z informatsiyno-komunikatsiynoiu sferoiu. Humanitarnyi visnyk Zaporizkoi derzh. inzhenernoi akademiyi, 61, 24-34.

22. Sosnin, O. V. (2003). Problemy derzhavnoho upravlinnia systemoiu natsionalnykh informatsiynykh resursiv $\mathrm{z}$ naukovoho potentsialu Ukrainy. Kyiv: Instytut derzhavy i prava im. V. M. Koretskoho NAN Ukrainy, 572.

23. Sosnin, O. V. (2015). Suchasni mizhnarodni systemy ta hlobalnyi rozvytok (sotsialno-politychni, sotsialno-ekonomichni ta sotsialno-antropolohichni vymiry). Kyiv: Tsentr navchalnoi literatury, 556.

СОСНІН, О. В. - доктор політичних наук, професор, професор, заслужений діяч науки і техніки України, академік Української академії політичних наук (Київ, Україна)

E-mail: alvas.sosnin@gmail.com, ORCID: 0000-0003-4188-0887

АЖАЖА М. А. - кандидат наук державного управління, доцент, доцент кафедри менеджменту організацій та управління проектами, Запорізька державна інженерна академія (Запоріжжя, Україна)

E-mail: azazmarina17@gmail.com, ORCID: 0000 -0001-6067-3926

\section{ІНФОРМАЦЙНО-КОМП'ЮТЕРНІ КОМУНІКАЦЇ̈ НАУКОВО- ОСВІТНЬОЇ ДІЯЛЬНОСТІ В УМОВАХ ІНТЕГРАЦІЇ УКРАЇНИ В ЄВРОПЕЙСЬКИЙ ОСВІТНІЙ ПРОСТІР}

Анотація. Актуальність дослідження в тому, що проаналізовано інформаційно-комп'ютерні комунікації науково-освітньої діяльності як чинник розвитку інформаційного суспільства. Постановка завдання сучасний етап суспільно-політичного розвитку України характеризується небаченими темпами розбудови нового інформаційно-комунікаційного облаштування науково-освітньої діяльності в суспільстві i, як наслідок, 
розбудови його як інформаційного і громадянського. Об'скт дослідження - інформаційно-комп'ютерні комунікації науково-освітньої діяльності як складний соціальний, культурний та економічний феномен. Предмет дослідження - вплив інформаційного суспільства на розвиток інформаційно-комп'ютерні комунікації науково-освітньої діяльності. Аналіз останніх публікацій і досліджень. Автор орієнтується на аналіз проблем інформаційного суспільства, які досліджувалися у роботах I.Валлерстайна, З.Бжезинського, Д.Белла, Дж.Гелбрейта, П.Друкера, А.Лазаревича, А.Портера, О.Тоффлера, Р.Хатчесона, а також вітчизняних В.Андрущенка, В.Воронкової, О.Кивлюк, М.Кириченка, О. Пунченка, Д.Свириденка. Виділення недосліджених частин загальної проблеми. Невирішені раніше частини загальної проблеми. Постановка завдання. Представники сучасного науково-освітнього середовища своєчасно не помітили, що з появою комп'ютера у світі суттєво змінилися фундаментальні уявлення про освіту, людину, науку, Всесвіт, темпоральні виміри часу, тенденції розвитку сучасного світу. Освіта визначає темпи розвитку світу, а за володіння їі ринками розпочалася небачена жорстка конкурентна боротьба. Інформація і знання стали величезним багатством, нематеріальним активом розвитку націй i держав. Методологія дослідження - використання методів синергетичного та аксіологічного, що сприяють глибокому проникненню в суть об'єкта та предмета дослідження.. Наукова новизна дослідження. Дане наукове дослідження передбачає звернення до соціально-філософського смислу концепції інформаційно-комп'ютерних комунікацій науково-освітньої діяльності як чинника розвитку інформаційного суспільства. Виклад основного матеріалу:. виявлено проблеми, що стосуються глобальної інформатизації суспільства, яка стимулювала всі процеси міжнародної співпраці людей, завдяки розвитку інформаційно-комунікаційної сфери збільшила потреби систем управління державами, суспільствами, їх громадянами в різноманітних інформаційних послугах, зумовила радикальні зміни в усіх системах безпеки суспільно-політичних відносин; проаналізовано історичну тенденцію розвитку індустріального, потім постіндустріального та інформаційного суспільства на основі концепції Й.Масуди; розкрито, що прогрес інформаційної й освітянської проблеми вимагають від нас зваженого облаштування освітніх інформаційнокомунікаційних систем i технологій освіти; обгрунтовано напрями удосконалення інформаційно-комп'ютерних комунікацій науковоосвітньої діяльності як чинник розвитку інформаційного суспільства.. Висновки - сформовано концепцію інформаційно-комп'ютерних комунікацій науково-освітньої діяльності як чинника розвитку інформаційного суспільства. Результат дослідження - розроблення напрямів реформування (модернізації) системи освіти в Україні та використання для цих цілей концепцій упровадження комп'ютерних інформаційно-комунікаційних технологій. 
Ключові слова: інформаційно-комп'ютерні комунікації, науковоосвітня діяльність, індустріальне суспільство, інформаційне суспільство, модернізація освіти

СОСНИН, А. В. - доктор политических наук, профессор, Заслуженный деятель науки и техники Украины, академик Украинской академии политических наук (Киев, Украина)

E-mail: alvas.sosnin@gmail.com, ORCID: 0000-0003-4188-0887

АЖАЖА, М. А. - кандидат наук государственного управления, доцент, доцент кафедры менеджмента организаций и управления проектами, Запорожская государственная инженерная академія (Запорожье, Украина)

E-mail: azazmarina17@gmail.com, ORCID: 0000 -0001-6067-3926

\section{ИНФОРМАЦИОННО-КОМПЬЮТЕРНЫЕ КОММУНИКАЦИИ} НАУЧНО-ОБРАЗОВАТЕЛЬНОЙ ДЕЯТЕЛЬНОСТИ В УСЛОВИЯХ ИНТЕГРАЦИИ УКРАИНЫ В ЕВРОПЕЙЙСКОЕ ПРОСТРАНСТВО

Аннотация. Актуальность исследования в том, что проанализированы информационно-компьютерные коммуникации научно-обрпазовательной деятельности как фактора развития информационного общества. Постановка задания - современный этап общественно-политического развития Украины характеризуется невиданными темпами нового информационно-коммуникационного обустройства научнообразовательной деятельности в обществе и, как следствие, формирования его как информационного и гражданского. Объект исследования информационно-компьютерные коммуникации научно-образовтельной деятельности как сложный социальный, культурнный и экономический феномен. Предмет исследования - влияние информационного общества на развитие информационно-компьютерных коммуникаций научнообразовательной деятельности. Анализ последних публикаций и исследований. Автор ориентируется на анализ проблем информационного общества, которые исследовались в работах И.Валлерстайна, 3.Бжезинского, Д.Белла, Дж.Гелбрейта, П.Друкера, А.Лазаревича, А.Портера, О.Тоффлера, Р.Хатчесона, а также отечественных В.Андрущенко, В.Воронковой, О.Кивлюк, Н.Кириченко, О.Пунченко, Д.Свириденко. Выделение неисследованных частей общей проблемы. Постановка задания. Представители современной научно-образовательной среды своевременно не заметили, что с появлением компьютера в мире существенно изменились современные представления об образовании, человеке, науке, Вселенной, темпоральных измерениях времени, тенденциях развития современного мира. Образование определяет темпы развития мира, а за владение его рынками началась невиданная конкурентная борьба. Информация и знания становятся огромным богатством, нематериальным активом развития наций и государств. 
Методология исследования - использование методов синергетического и аксиологического, которые содействуют глубокому проникновению в сущность объекта и предмета исследования. Научная новизна исследования. Данное научное исследование предвидит обращение к социально-философскому смыслу концепции информационнокомпьютерных коммуникаций научно-образовательной деятельности как фактора развития информационного общества. Изложение основного материала: выявлены проблемы, которые касаются глобальной информатизации общества, которые стимулировали все процессы международного сотрудничества людей, благодаря развитию информационно-комммуникационной сферы, которая увеличила потребности систем управления государствами, обществами, их гражданами в разнообразных информационных услугах, обусловила радикальные изменения во всех системах безопасности общественнополитических отношений; проанализирована историческая тенденция развития индустриального, затем постиндустриального и информационного общества на основе концепции И.Масуды; раскрыто, что прогресс информационного и образовательного общества требуют от государства умеренного обустройства образовательных информационнокоммуникационных систем и технологий образования; обоснованы направления усовершенствования информационно-компьютерных коммуникаций научно-образовательной деятельности как фактор развития информационного общества. Выводы - сформирована концепция информационно-компьютерных коммуникаций научно-образовательной деятельности как фактора развития информационного общества. Результат исследования - разработка направлений реформирования (модернизации) системы образования в Украине и использование для этих целей концепций внедрения компьютерных информационно-коммуникационных технологий.

Ключевые слова: информационно-компьютерные коммуникации, научно-образовательная деятельность, индустриальное общество, информационное общество, модернизация образования

Стаття рекомендована до публікації д.філософ.н., проф. О. П. Пунченко (Одеса, Украӥна)

Надійила до редколегї: 13.10.2018 Прийнята до друку: 18.10.2018 